\title{
Clinical evaluation of periodontal status associated with class II direct posterior restorations - Preliminary clinical study
}

\author{
Evaluarea clinică a statusului parodontal asociat \\ restaurărilor posterioare directe de clasa a II-a - Studiu clinic preliminar
}

\author{
Andreea Ciurea ${ }^{1}$, Iulia Cristina Micu', Alexandra Roman ${ }^{1,2}$, \\ Daniela Condor ${ }^{1,2}$, Andrada Soancă ${ }^{1,2}$ \\ ${ }^{1}$ Disciplina Parodontologie, Facultatea de Medicină Dentară, \\ Universitatea de Medicină și Farmacie „Iuliu Hațieganu“, Cluj-Napoca, România \\ ${ }^{2}$ Spitalul Clinic Județean de Urgență, Cluj-Napoca, România
}

\begin{abstract}
Aim. This clinical study aimed to evaluate the following periodontal parameters: plaque indices, bleeding indices, probing depth and attachment loss, for class II direct posterior restorations.

Material and method. The direct posterior restorations were performed with two ormocer materials, Admira Fusion X-tra ${ }^{\circledR}$ (Voco, Cuxhaven, Germania) and Admira Fusion ${ }^{\circledR}$ (Voco Cuxhaven, Germania), through two different methods, bulk fill technique and proximal wall restoration technique. The periodontal parameters were followed in 4 different moments, over a period of 3 months.

Results. At the evaluation of plaque indices and bleeding indices, no significant differences were observed between the 2 studied groups. In both of the followed groups, group I and group II, the values for plaque and bleeding indices were decreased during the evaluation period. The values of probing depth and attachment loss did not change at any of the evaluation moment.

Conclusions. Ormocer materials and restoration techniques used in this study did not negatively influence the evaluated periodontal parameters.
\end{abstract}

Keywords: direct proximal restorations, ormocers, plaque indices, bleeding indices, probing depth, attachement loss

\section{REZUMAT}

Obiective. Studiul clinic a avut în vedere evaluarea următorilor parametri paradontali: indici de placă, indici de sângerare, profunzime la sondare și pierdere de atașament, pentru restaurări posterioare directe de clasa a II-a. Material şi metodă. Restaurările posterioare directe au fost realizate cu două materiale ormocere, Admira Fusion X-tra ${ }^{\circledR}$ (Voco, Cuxhaven, Germania) și Admira Fusion ${ }^{\circledR}$ (Voco, Cuxhaven, Germania), prin două tehnici diferite, tehnica bulk fill și tehnica de refacere a peretului proximal. Evaluarea parametrilor parodontali s-a realizat pe o perioadă de 3 luni, în 4 momente diferite.

Rezultate. La evaluarea indicilor de placă și a indicilor de sângerare nu au fost observate diferențe semnificative între cele 2 loturi studiate. Atât în lotul I, cât și în lotul II au fost observate scăderi ale valorilor indicilor de placă și de sângerare pe perioada de evaluare.Valorile profunzimii la sondare și a pierderii de atașament nu s-au modificat în niciunul dintre momentele de evaluare.

Concluzii. Materialele ormocere și tehnicile de restaurare utilizate în prezentul studiu nu au influențat în mod negativ niciunul dintre parametrii parodontali evaluați.

Cuvinte cheie: restaurări directe proximale, ormoceri, indici de placă, indici de sângerare, profunzime la sondare, pierdere de atașament

\section{INTRODUCERE}

Materialele dentare compozite sunt cele mai folosite materiale de restaurare dentară directă pentru tratarea leziunilor carioase de clasa I și a II-a ale dinţilor posteriori. Principalele avantaje ale utilizării acestor materiale se referă la permiterea preparării unor cavități conservatoare, fără a fi necesară 
realizarea unor zone de retenție macromecanice și păstrarea și conservarea la maximum a țesutului sănătos dentar [1]. Succesul clinic al restaurărilor compozite directe a dinţilor posteriori se bazează și pe posibilitatea acestora de redare a nuanței naturale a dinţilor și pe proprietăţile fizice și mecanice adecvate ale acestui grup de materiale [2].

Stresul rezultat în urma polimerizării reprezintă încă limitări ale restaurărilor compozite, deși s-au realizat multe îmbunătățiri ale compozitelor pe bază de răşini. Contracția de polimerizare cauzează stres şi contracție volumetrică crescută la nivelul restaurării, conducând astfel la apariția microinfiltrației marginale bacteriene [3]. Microinfiltraţia marginală se definește ca fiind trecerea nedetectabilă la interfaţa dinte-restaurare a bacterilor, ionilor şi lichidelor [4].

Pentru a depăși problemele materialelor compozite convenționale pe bază de răşini, au fost introduse pe piaţa materialelor dentare de restaurare directă ormocerii (materiale ceramice modificate organic) [5]. Materialele ormocere prezintă contracție de polimerizare mai scăzută [6], astfel că, în timp ce materialele compozite convenționale pe bază de rășini prezintă o contracție volumetrică între $2 \%$ și $6 \%$, materialele ormocere prezintă o contracție volumetrică de doar 1,25\% [7].

Chiar și în cadrul grupului de materiale ormocere s-au adus ameliorări proprietăților acestora. Astfel, pentru că materialul Admira Fusion ${ }^{\circledR}$ (Voco, Cuxhaven, Germania), care este un ormocer convențional, se aplică în straturi de până la maximum $2 \mathrm{~mm}$, s-a propus varianta ormocer de tip bulk fill, comercializată sub denumirea de Admira Fusion X-tra ${ }^{\circledR}$. Acest ormocer bulk fill are o transluciditate crescută, astfel că poate permite o adâncime mai mare de polimerizare și poate fi aplicat în straturi de pănâ la 4 mm, reducând astfel timpul de lucru.

\section{SCOP}

Scopul studiului a fost evaluarea indicilor de placă, a indicilor de sângerare, a profunzimii la sondare și a pierderii de atașament la 30 de restaurări posterioare directe de clasa a II-a realizate cu două materiale ormocere, prin două tehnici diferite. Restaurările au fost evaluate pe o perioadă de 3 luni, în 4 momente diferite, preoperator, la 14 zile, la 1 lună și la 3 luni postoperator.

\section{MATERIAL ŞI METODĂ}

Acest studiu clinic s-a desfășurat la Disciplina de Parodontologie, de la Facultatea de Medicină Dentară, din cadrul Universității de Medicină și Farmacie „Iuliu Haţieganu“ din Cluj-Napoca, cu aprobarea Comisiei de Etică a Universităţii de Medicină şi Farmacie „Iuliu Hațieganu“ din Cluj-Napoca (Nr. 56 din 03.02.2017) și a Spitalului Clinic Județean de Urgență Cluj-Napoca (Nr. 25374/B din 07.11.2018).

De asemenea, Spitalul Clinic Județean de Urgență Cluj-Napoca și-a exprimat avizul pentru publicarea rezultatelor studiilor din cadrul cercetărilor doctorale (Nr. 25374/B din 07.11.2018).

Scopul studiului și implicațiile tratamentului au fost explicate pacienților care au fost de acord să participe la acest studiu prin semnarea consimțământului informat.

Acest studiu clinic preliminar a avut în vedere realizarea de 30 de restaurări posterioare directe, de clasa a II-a, folosind două materiale ormocere Admira Fusion X-tra ${ }^{\circledR}$ (Voco) și Admira Fusion ${ }^{\circledR}$ (Voco), aplicate prin tehnica bulk fill, respectiv tehnica de refacere a peretelui proximal. S-a dorit evaluarea indicilor de placă, a indicilor de sângerare, profunzimea la sondare și pierderea de ataşament preoperator şi în 3 momente diferite postoperator (la 14 zile, la 1 lună și 3 luni).

Criteriile folosite pentru selectarea pacienților în studiul clinic au fost:

- criteriile de includere - minimum o leziune carioasă primară sau secundară, de clasa a IIa, pe dinți permanenți vitali cu simptomatologie de carie simplă sau devitali cu tratament endodontic corect radiografic, prezența dintelui adiacent leziunii carioase în contact cu dintele de studiu, absența coafajului direct pe dintele de studiu, igienă dentară bună (indice de placă $\mathrm{IHI}<25 \%$ ).

- criteriile de excludere - afecțiuni sistemice grave, care contraindică tratamentul stomatologic, alergii la materialele dentare, distrucții coronare mari care contraindică realizarea unei restaurări directe, dinţi devitali cu tratament endodontic incorect realizat, coafaj direct în antecedente pe dintele de studiu, leziuni pulpare netratate, absența dintelui vecin, leziuni carioase, igienă orală nesatisfăcătoare. 
După aplicarea criteriilor de includere/excludere, în studiu au fost incluși 24 de pacienți adulți.

Leziunile odontale $(\mathrm{n}=36)$ au fost aleator împărțite pentru a fi restaurate, în două grupuri, printr-un proces simplu de randomizare. Astfel, au rezultat două loturi de studiu: lotul I - format din restaurări realizate cu Admira Fusion X-tra ${ }^{\circledR}$ plasate prin tehnica bulk fill, iar lotul II a fost format din restaurări realizate cu Admira Fusion ${ }^{\circledR}$ plasate prin tehnica de refacere a peretelui proximal.

\section{Înregistrarea parametrilor parodontali}

Indicii de placă și indicii de sângerare au fost evaluaţi în 4 puncte (mezio, centro și disto-vestibular și centro-oral) la nivelul dintelui de restaurat și la 2 dinţi vecini, unul mezial și unul distal de cel experimental, evaluând în total 12 locusuri.

Indicele de placă localizat (IPL) a fost realizat prin tehnica raclării plăcii bacteriene prezente la nivelul coletului dinţilor examinați, cu ajutorul unei sonde parodontale. Prezența plăcii bacteriene s-a înregistrat cu semnul + sau absența acesteia cu semnul -.

Indicele de sângerare a fost realizat prin tehnica de provocare a sângerării gingivale, adică prin introducerea sondei parodontale în sulcus, paralel cu axa dintelui, până la baza acestuia fără a o atinge (fără a leza epiteliul joncţional) şi deplasarea circumferenţială o singură dată, cu o forţă de sondare sub 25 g, iar înregistarea rezultatelor (+ prezenţa sângerării și - absența sângerării) s-a realizat după 30 de secunde [8].

Indicii de placă și de sângerare s-au cuantificat prin realizarea unui scor mediu procentual pentru fiecare grup de dinţi examinați, pentru fiecare moment de evaluare.

Profunzimea la sondare și pierderea de ataşament s-au evaluat în 4 puncte - mezio-vestibular (MV), disto-vestibular (DV), disto-lingual (DL) și meziolingual (ML) - la nivelul dintelui experimental.

Profunzimea la sondare s-a măsurat de la marginea gingivală liberă până la baza sulcusului/pungii.

Pierderea de atașament $\mathrm{s}-\mathrm{a}$ măsurat de la joncțiunea amelo-cementară până la baza sulcusului/pungii.

Toate examinările au fost realizate cu sonda parodontală UNC $15^{\circledR}$ (University of North Carolina Hu Friedy).
Protocolul clinic de restaurare a fost publicat anterior [9].

Pe scurt, cavitățile au fost preparate conform regulilor generale de preparare a cavităților restaurate adeziv, iar pentru refacerea contururilor proximale s-a folosit sistemul de matrici segmentare Palo$\operatorname{dent}^{\circledR}$ V3 (Dentsply Sirona, Konstanz, Germania). Sistemul adeziv utilizat a fost Futurabond $\mathrm{M}+$ (Voco, Cuxhaven, Germania), care a fost aplicat în cavităţi conform indicaţiilor producătorului. Materialul de restaurare, Admira Fusion X-tra ${ }^{\circledR}$, a fost folosit prin tehnica bulk fill, tehnică ce a presuspus aplicarea acestuia în straturi de $4 \mathrm{~mm}$. Materialul de restaurare Admira Fusion ${ }^{\circledR}$ a fost folosit prin tehnica de refacere a peretului proximal, care a constat în refacerea peretului amelar absent prin aplicarea unui strat subțire de material, de 0,5 mm, pe peretele gingival și aplicarea de straturi succesive pănâ la refacerea completă a acestuia, urmând îndepărtarea matricii și aplicarea de straturi succesive oblice de material până la umplerea cavității.

După finalizarea restaurărilor, au urmat finisarea și verificarea corectitudinii punctelor de contact, a închiderii marginale și a texturii suprafeței.

\section{Analiza statistică}

A fost calculată statistica descriptivă, iar pentru testarea distribuţiei normale s-a folosit testul Shapiro-Wilk, iar variația a fost testată cu testul F. În cazul datelor cu distribuţie normală, s-a utilizat testul t (Student), iar în cazul valorilor cu distribuţie neuniformă sau a rangurilor au fost utilizate testele neparametrice Mann-Whitney (U), pentru două probe neperechi, sau Wilcoxon, în cazul a două probe perechi. Pentru decelarea corelaţiei dintre două variabile cantitative continue, cu distribuţie normală (uniformă), s-a utilizat coeficientul de corelaţie Pearson (r). În cazul variabilelor cu distribuţie neuniformă, s-a utilizat coeficientul de corelaţie a rangurilor Spearman $(\rho)$. Analiza coeficienţilor de corelaţie s-a efectuat utilizând regula lui Colton. Pragul de semnificaţie pentru testele folosite a fost $\alpha=0,05$ (5\%), 0,01 (1\%) sau 0,001 .

Prelucrarea statistică s-a efectuat cu aplicaţia Excel (din pachetul Microsoft Office 2010) şi cu programul StatsDirect v.2.7.2. Reprezentarea grafică a rezultatelor s-a făcut cu aplicaţia Excel (din pachetul Microsoft Office 2010). 


\section{REZULTATE}

În prezentul studiu, s-a dorit evaluarea indicilor de placă și de sângerare, a profunzimii la sondare și a pierderii de ataşament pentru 30 de restaurări posterioare directe (18 restaurări realizate cu Admira Fusion X-tra ${ }^{\circledR}$ - lot I și 12 restaurări cu Admira Fusion $^{\circledR}$ - lot II), pe o periodă de 3 luni, în 4 momente diferite, momentul O (T0), la 14 zile postoperator (T1), la 1 lună (T2) și la 3 luni postoperator (T3).

În continuare, se prezintă evoluția parametrilor parodontali pentru cele două loturi.

\section{Indicii de placă}

La analiza statistică a valorilor indicilor de placă (\%) pentru probe neperechi, nu au fost observate diferenţe statistic semnificative $(p>0,05)$ între cele 2 loturi, I și II, în niciunul dintre momentele de timp studiate.

La analiza statistică a valorilor indicilor de placă (\%) pentru probe perechi, au fost observate la lotul I diferenţe statistic semnificative între T0 şi T3 $(\mathrm{p}<0,01)$ şi diferenţe statistic semnificative între T1 şi T3 (p < 0,05) (tabel 1, figura 1).

Reprezentarea grafică (figura 1) ilustrează media indicilor de placă, pentru cele două loturi studiate. În ambele loturi s-a observat o ușoară scădere a mediei indicilor de placă pe perioada de evaluare. În lotul I, media indicilor de placă a scăzut în fiecare moment de evaluare. Astfel, media indicilor de placă înregistrată în T0 și T1 a fost aproximativ egală $(38,39$, respectiv 38,89$)$, în T2 s-a înregistrat o scădere a mediei $(29,84)$ comparativ cu T0 și T1, iar în T3 s-a înregistrat cea mai scăzută medie $(26,89)$. În lotul II s-a observat o descreștere a mediei indicilor de placă, de la T0 $(44,58)$ la T3 $(34,92)$.

\section{Indicii de sângerare}

La analiza statistică a valorilor indicilor de sângerare (\%) pentru probe neperechi, nu au fost observate diferenţe statistic semnificative $(\mathrm{p}>0,05)$ între cele 2 loturi, I și II, în niciunul dintre momentele de timp studiate.

TABEL 1. Analiza comparativă pentru valorile indicilor de placă (\%) la loturile studiate şi semnificația statistică

\begin{tabular}{|c|c|c|c|c|c|c|c|c|c|c|c|c|c|}
\hline Lot & Moment & Media & ES & Mediana & DS & Min & Max & \multicolumn{6}{|c|}{ Semnificația statistică (p) } \\
\hline \multirow{4}{*}{ I } & TO & 38,39 & 4,71 & 33 & 19,97 & 8 & 75 & \multirow{4}{*}{ I-II } & TO & 0,6956 & \multirow[b]{2}{*}{1} & T1-T3 & 0,0419 \\
\hline & T1 & 38,89 & 5,62 & 33 & 23,84 & 8 & 100 & & T1 & 0,8378 & & T2-T3 & 0,1309 \\
\hline & $\mathrm{T} 2$ & 29,83 & 4,06 & 25 & 17,22 & 0 & 66 & & T2 & 0,1317 & \multirow{6}{*}{ |I } & T0-T1 & 0,75 \\
\hline & T3 & 26,89 & 4,03 & 25 & 17,08 & 0 & 75 & & T3 & 0,1264 & & T0-T2 & 0,1875 \\
\hline \multirow{4}{*}{ II } & TO & 44,58 & 6,43 & 37 & 22,27 & 25 & 87 & \multirow{4}{*}{1} & T0-T1 & 0,6953 & & TO-T3 & 0,1094 \\
\hline & T1 & 39,75 & 5,73 & 33 & 19,85 & 12 & 75 & & T0-T2 & 0,1726 & & T1-T2 & 0,875 \\
\hline & T2 & 37,42 & 3,48 & 37 & 12,04 & 25 & 50 & & T0-T3 & 0,0084 & & T1-T3 & 0,4375 \\
\hline & T3 & 34,92 & 4,82 & 33 & 16,71 & 0 & 62 & & T1-T2 & 0,0923 & & T2-T3 & 0,625 \\
\hline
\end{tabular}

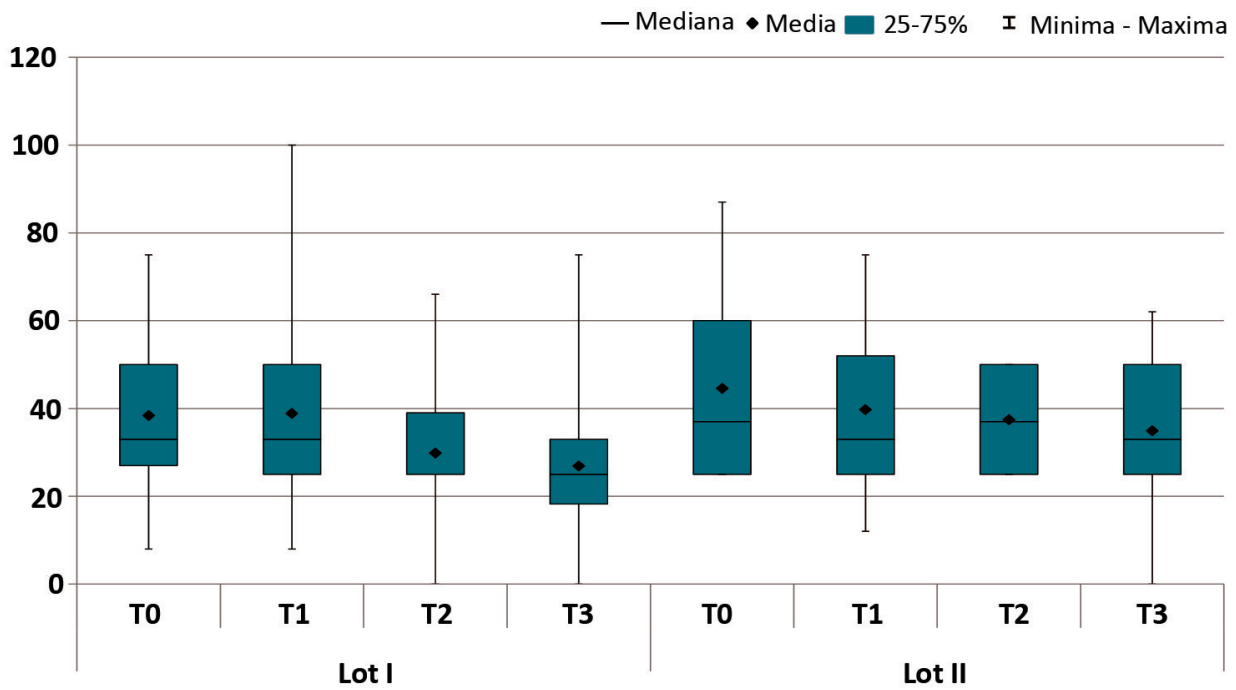

FIGURA 1. Indicii de placă pentru lotul I şi lotul II pe o perioadă de 3 luni 
TABEL 2. Analiza comparativă pentru valorile indicilor de sângerare (\%) la loturile studiate şi semnificația statistică

\begin{tabular}{|c|c|c|c|c|c|c|c|c|c|c|c|c|c|}
\hline Lot & Moment & Media & ES & Mediana & DS & Min & Max & & Sen & ificația s & atis & ică (p) & \\
\hline \multirow{4}{*}{ I } & T0 & 29,50 & 5,88 & 16 & 24,94 & 0 & 75 & \multirow{4}{*}{$I-I I$} & TO & 0,2208 & \multirow{2}{*}{ I } & T1-T3 & 0,6355 \\
\hline & T1 & 17,28 & 4,22 & 8 & 17,91 & 0 & 58 & & T1 & 0,5502 & & T2-T3 & 0,2031 \\
\hline & $\mathrm{T} 2$ & 17,50 & 5,06 & 14 & 21,46 & 0 & 66 & & $\mathrm{~T} 2$ & 0,3921 & \multirow{6}{*}{ II } & T0-T1 & 0,5 \\
\hline & T3 & 13,28 & 3,74 & 8 & 15,89 & 0 & 50 & & T3 & 0,3876 & & T0-T2 & 0,125 \\
\hline \multirow{4}{*}{ II } & TO & 21,67 & 8,92 & 12 & 30,90 & 0 & 100 & \multirow{4}{*}{ I } & T0-T1 & 0,0923 & & T0-T3 & 0,0313 \\
\hline & T1 & 17,92 & 8,20 & 8 & 28,40 & 0 & 100 & & T0-T2 & 0,1272 & & T1-T2 & 0,125 \\
\hline & T2 & 14,75 & 8,26 & 4 & 28,61 & 0 & 100 & & T0-T3 & 0,0295 & & T1-T3 & 0,0313 \\
\hline & T3 & 8,58 & 4,36 & 0 & 15,11 & 0 & 50 & & T1-T2 & 0,9697 & & T2-T3 & 0,25 \\
\hline
\end{tabular}

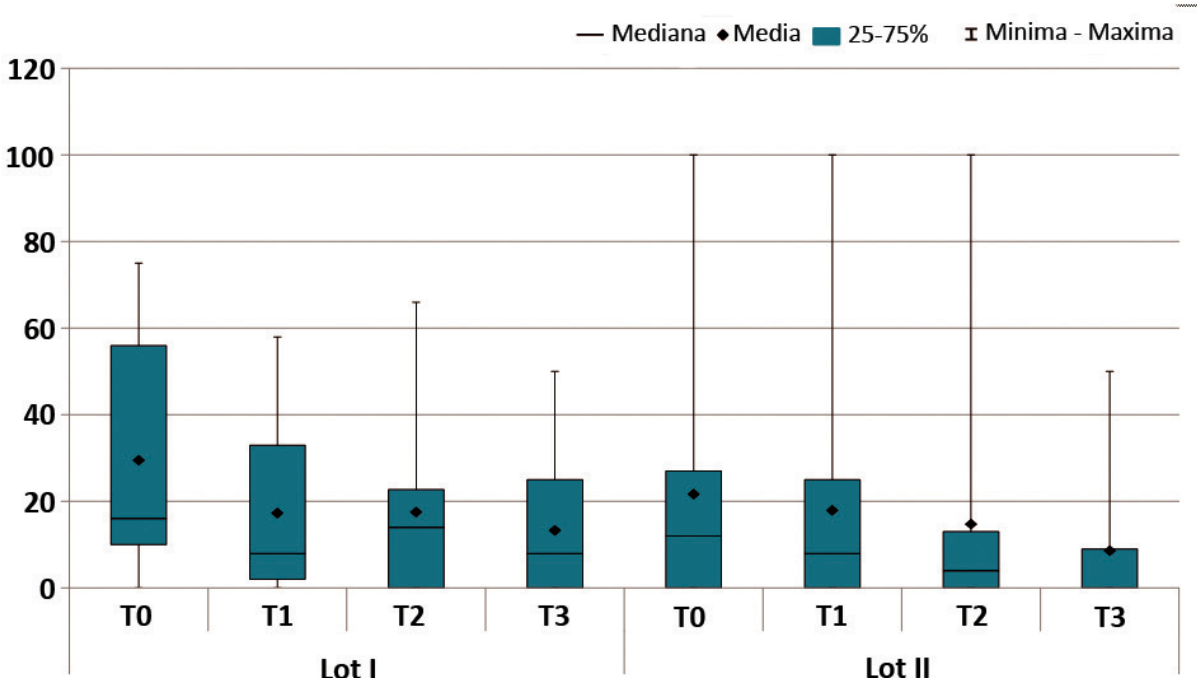

FIGURA 2. Indicii de sângerare pentru lotul I şi lotul II pe o perioadă de 3 luni

La analiza statistică a valorilor indicilor de sângerare (\%) pentru probe perechi, au fost observate:

- la lot I-diferenţe statistic semnificative între T0 şi T3 $(\mathrm{p}<0,05)$

- la lot II - diferenţe statistic semnificative între T0-T3 şi T1-T3 (p < 0,05) (tabel 2, figura 2).

Reprezentarea grafică (figura 2) ilustrează media indicilor de sângerare pentru cele două loturi studiate. În ambele loturi s-a observat o scădere a mediei indicilor de sângerare pe perioada de evaluare. În lotul I, media indicilor de sângerare a scăzut în fiecare moment de evaluare, în T0 s-a înregistrat o medie de 29,50, în T1 și T2 media înregistrată a fost aproximativ egală, 17,28, respectiv 17,50, iar în T3 media înregistrată a fost 13,28. În lotul II, s-a observat o descreștere a mediei indicilor de sângerare, astfel: în T0, a fost 21,67, în T1 şi T2 s-au înregistrat scăderi ale acesteia, media fiind 17,92, respectiv 15,75, iar în T3 media înregistrată a fost cea mai scăzută, 8,58 .

\section{Profunzimea la sondare}

Profunzimea la sondare (PD) s-a evaluat în 4 puncte la nivelul fiecărui dinte experimental.

La analiza statistică a valorilor PD-MV (profunzime la sondare mezio-vestibulară) pentru probe neperechi au fost observate diferenţe statistic semnificative $(\mathrm{p}<0,05)$ între cele 2 loturi la momentul T0, dar nu au fost observate diferențe statistic semnificative în celelalte momente de timp.

La analiza statistică a valorilor PD-MV pentru probe perechi au fost observate la lotul I diferenţe statistic semnificative între T0 şi T3 $(\mathrm{p}<0,05)$ (tabel 3, figura 3).

Reprezentarea grafică (figura 3) ilustrează media valorilor obținute la măsurarea profunzimii la sondare mezio-vestibulară, pentru cele două loturi studiate. Valorile obținute au fost constante pentru ambele loturi, în toate cele 4 momente de evaluare.

La analiza statistică a valorilor PD-DV (profunzime la sondare disto-vestibulară) pentru probe ne- 
TABEL 3. Analiza comparativă pentru valorile PD-MV la loturile studiate şi semnificația statistică

\begin{tabular}{|c|c|c|c|c|c|c|c|c|c|c|c|c|c|}
\hline Lot & Moment & Media & ES & Mediana & DS & Min & Max & \multicolumn{6}{|c|}{ Semnificația statistică (p) } \\
\hline \multirow{4}{*}{ I } & TO & 2,67 & 0,18 & 3 & 0,77 & 1 & 4 & \multirow{4}{*}{ I-II } & TO & 0,0144 & \multirow{2}{*}{ I } & T1-T3 & 0,125 \\
\hline & T1 & 2,44 & 0,20 & 2 & 0,86 & 1 & 4 & & T1 & 0,0965 & & T2-T3 & 0,5 \\
\hline & $\mathrm{T2}$ & 2,33 & 0,20 & 2 & 0,84 & 1 & 4 & & T2 & 0,1571 & \multirow{6}{*}{ II } & T0-T1 & $>0,9999$ \\
\hline & T3 & 2,22 & 0,17 & 2 & 0,73 & 1 & 4 & & T3 & 0,2479 & & T0-T2 & $>0,9999$ \\
\hline \multirow{4}{*}{ II } & TO & 2,00 & 0,33 & 2 & 1,13 & 1 & 5 & \multirow{4}{*}{ I } & T0-T1 & 0,3125 & & TO-T3 & $>0,9999$ \\
\hline & T1 & 1,92 & 0,26 & 2 & 0,90 & 1 & 4 & & T0-T2 & 0,0625 & & T1-T2 & $>0,9999$ \\
\hline & $\mathrm{T} 2$ & 1,83 & 0,21 & 2 & 0,72 & 1 & 3 & & T0-T3 & 0,0156 & & T1-T3 & $>0,9999$ \\
\hline & T3 & 1,83 & 0,21 & 2 & 0,72 & 1 & 3 & & T1-T2 & 0,5 & & T2-T3 & $>0,9999$ \\
\hline
\end{tabular}

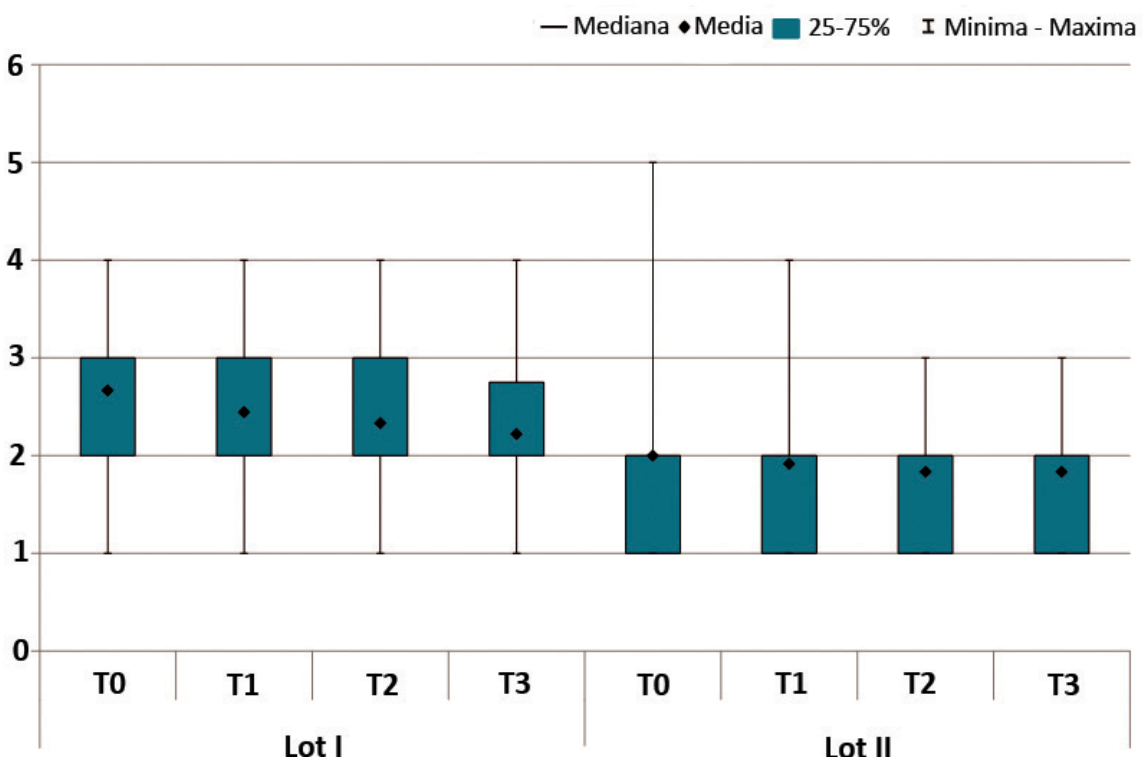

FIGURA 3. Profunzimea la sondarea mezio-vestibulară pentru lotul I şi lotul II pe o perioadă de 3 luni

TABEL 4. Analiza comparativă pentru valorile PD-DV la loturile studiate şi semnificația statistică

\begin{tabular}{|c|c|c|c|c|c|c|c|c|c|c|c|c|c|}
\hline Lot & Moment & Media & ES & Mediana & DS & Min & Max & \multicolumn{6}{|c|}{ Semnificația statistică (p) } \\
\hline \multirow{4}{*}{ I } & TO & 3,00 & 0,33 & 3 & 1,41 & 1 & 7 & \multirow{4}{*}{ I-II } & TO & 0,384 & \multirow{2}{*}{ I } & T1-T3 & 0,5 \\
\hline & T1 & 2,83 & 0,22 & 3 & 0,92 & 1 & 4 & & T1 & 0,3583 & & T2-T3 & 0,75 \\
\hline & T2 & 2,67 & 0,20 & 3 & 0,84 & 1 & 4 & & $\mathrm{T2}$ & 0,672 & \multirow{6}{*}{ II } & T0-T1 & $>0,9999$ \\
\hline & T3 & 2,72 & 0,19 & 3 & 0,83 & 1 & 4 & & T3 & 0,3262 & & T0-T2 & $>0,9999$ \\
\hline \multirow{4}{*}{ II } & TO & 2,50 & 0,26 & 3 & 0,90 & 1 & 4 & \multirow{4}{*}{ I } & T0-T1 & 0,8125 & & T0-T3 & $>0,9999$ \\
\hline & T1 & 2,50 & 0,26 & 3 & 0,90 & 1 & 4 & & T0-T2 & 0,3828 & & T1-T2 & $>0,9999$ \\
\hline & $\mathrm{T2}$ & 2,50 & 0,26 & 3 & 0,90 & 1 & 4 & & T0-T3 & 0,4961 & & T1-T3 & $>0,9999$ \\
\hline & T3 & 2,42 & 0,26 & 2,5 & 0,90 & 1 & 4 & & T1-T2 & 0,3125 & & T2-T3 & $>0,9999$ \\
\hline
\end{tabular}

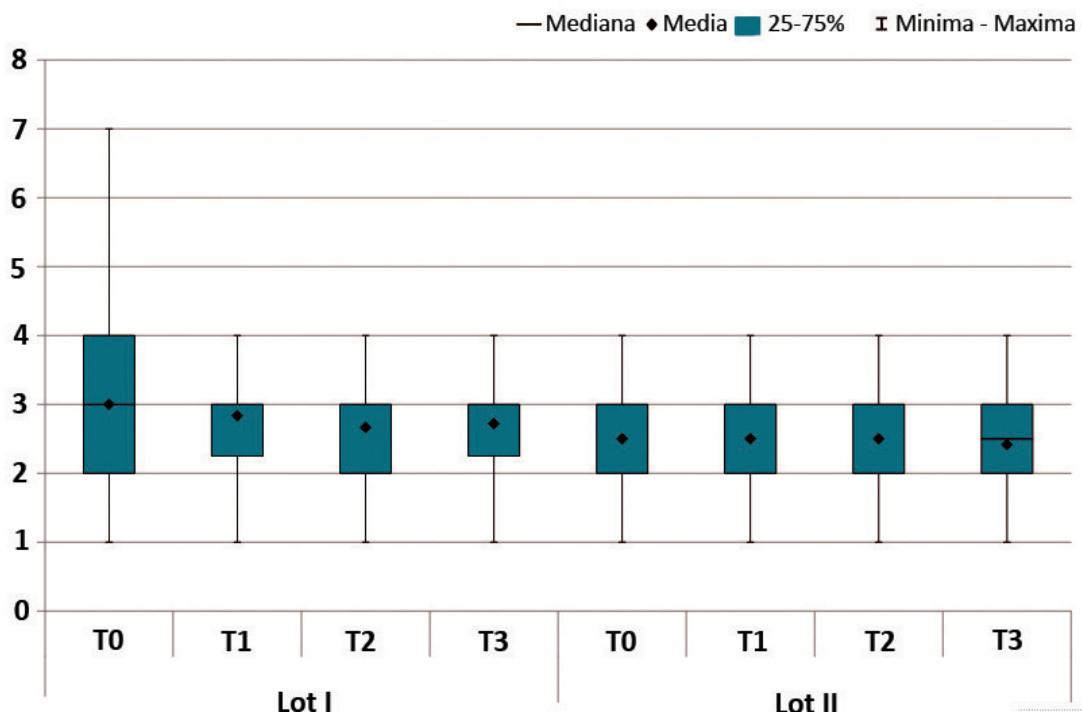

FIGURA 4. Profunzimea la sondare disto-vestibulară pentru lotul I şi lotul II pe o periodă de 3 luni 
perechi nu au fost observate diferenţe statistic semnificative $(p>0,05)$ între cele 2 loturi în niciunul dintre momentele de timp studiate. La analiza statistică a valorilor PD-DV pentru probe perechi nu au fost observate diferenţe statistic semnificative ( $p$ $>0,05)$ între niciunul dintre momentele de timp studiate la niciunul dintre loturi (tabel 4, figura 4).

Reprezentarea grafică (figura 4) ilustrează media valorilor obținute la măsurarea profunzimii la sondare disto-vestibulară, pentru cele două loturi studiate. Valorile obținute au fost similare și constante pentru ambele loturi, în toate cele 4 momente de evaluare.

La analiza statistică a valorilor PD-DL (profunzime la sondare disto-linguală) pentru probe neperechi nu au fost observate diferenţe statistic semnificative $(\mathrm{p}>0,05)$ între cele 2 loturi în niciunul dintre momentele de timp studiate.

La analiza statistică a valorilor PD-DL pentru probe perechi, nu au fost observate diferenţe statistic semnificative $(p>0,05)$ între niciunul dintre momentele de timp studiate la niciunul dintre loturi (tabel 5, figura 5).

Reprezentarea grafică (figura 5) ilustrează media valorilor obținute la măsurarea profunzimii la sondare disto-linguală, pentru cele două loturi studiate. Valorile obținute au fost similare și constante pentru ambele loturi, în toate cele 4 momente de evaluare.

La analiza statistică a valorilor PD-ML (profunzimea la sondare mezio-linguală) pentru probe neperechi nu au fost observate diferenţe statistic semnificative $(p>0,05)$ între cele 2 loturi în niciunul dintre momentele de timp studiate.

La analiza statistică a valorilor PD-ML pentru probe perechi nu au fost observate diferenţe statistic semnificative $(p>0,05)$ între niciunul dintre momentele de timp studiate la niciunul dintre loturi (tabel 6, figura 6).

Reprezentarea grafică (figura 6) ilustrează media valorilor obținute la măsurarea profunzimii la sondare mezio-linguală, pentru cele două loturi studiate.

\section{Pierderea de ataşament}

Pierderea de ataşament (PA) s-a evaluat în 4 puncte la nivelul fiecărui dinte experimental.

La analiza statistică a valorilor PA-MV (pierdere de ataşament mezio-vestibulară) pentru probe neperechi nu au fost observate diferenţe statistic

TABEL 5. Analiza comparativă pentru valorile PD-DL la loturile studiate şi semnificația statistică

\begin{tabular}{|c|c|c|c|c|c|c|c|c|c|c|c|c|c|}
\hline Lot & Moment & Media & ES & Mediana & DS & Min & Max & & & nnificați & stat & istică (p) & \\
\hline \multirow{4}{*}{1} & TO & 2,83 & 0,28 & 3 & 1,20 & 1 & 6 & \multirow{4}{*}{$I-I I$} & TO & 0,6796 & \multirow{2}{*}{ I } & T1-T3 & 0,3125 \\
\hline & T1 & 2,67 & 0,24 & 3 & 1,03 & 1 & 6 & & T1 & 0,6008 & & T2-T3 & 0,5 \\
\hline & T2 & 2,56 & 0,17 & 3 & 0,70 & 1 & 4 & & $\mathrm{~T} 2$ & 0,6327 & \multirow{6}{*}{ II } & T0-T1 & 0,5 \\
\hline & T3 & 2,44 & 0,17 & 2 & 0,70 & 1 & 4 & & T3 & 0,9554 & & T0-T2 & 0,5 \\
\hline \multirow{4}{*}{ II } & TO & 2,58 & 0,40 & 3 & 1,38 & 1 & 5 & \multirow{4}{*}{ I } & T0-T1 & 0,6406 & & T0-T3 & 0,75 \\
\hline & T1 & 2,33 & 0,33 & 2,5 & 1,15 & 1 & 4 & & T0-T2 & 0,5197 & & T1-T2 & $>0,9999$ \\
\hline & T2 & 2,33 & 0,33 & 2,5 & 1,15 & 1 & 4 & & T0-T3 & 0,2846 & & T1-T3 & $>0,9999$ \\
\hline & T3 & 2,42 & 0,31 & 2,5 & 1,08 & 1 & 4 & & T1-T2 & 0,75 & & T2-T3 & $>0,9999$ \\
\hline
\end{tabular}

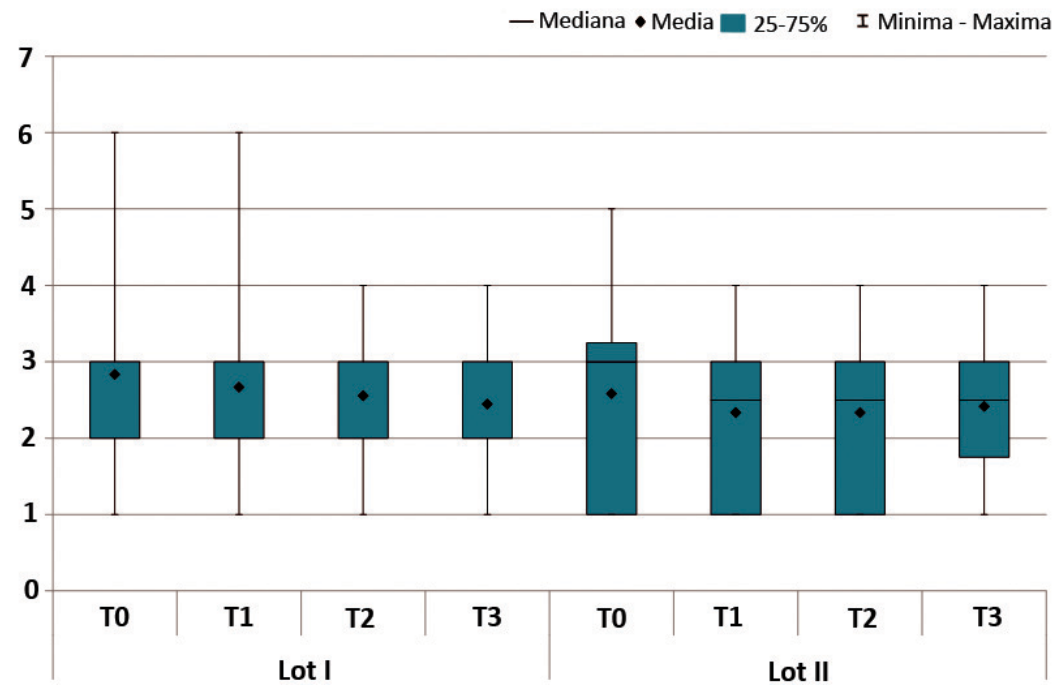

FIGURA 5. Profunzimea la sondare disto-linguală pentru lotul I şi lotul II pe o perioadă de 3 luni 
TABEL 6. Analiza comparativă pentru valorile PD-ML la loturile studiate şi semnificația statistică

\begin{tabular}{|c|c|c|c|c|c|c|c|c|c|c|c|c|c|}
\hline Lot & Moment & Media & ES & Mediana & DS & Min & Max & \multicolumn{6}{|c|}{ Semnificația statistică (p) } \\
\hline \multirow{4}{*}{ I } & TO & 2,61 & 0,27 & 2 & 1,14 & 1 & 5 & \multirow{4}{*}{$I-I I$} & TO & 0,496 & \multirow{2}{*}{$\mathbf{I}$} & T1-T3 & 0,6406 \\
\hline & T1 & 2,72 & 0,28 & 2 & 1,18 & 1 & 5 & & T1 & 0,3369 & & T2-T3 & 0,75 \\
\hline & T2 & 2,39 & 0,20 & 2 & 0,85 & 1 & 4 & & T2 & 0,6544 & \multirow{6}{*}{ II } & T0-T1 & $>0,9999$ \\
\hline & T3 & 2,50 & 0,19 & 2 & 0,79 & 1 & 4 & & T3 & 0,3877 & & T0-T2 & $>0,9999$ \\
\hline \multirow{4}{*}{ II } & TO & 2,33 & 0,26 & 2 & 0,89 & 1 & 4 & \multirow{4}{*}{ I } & T0-T1 & 0,625 & & T0-T3 & $>0,9999$ \\
\hline & $\mathrm{T1}$ & 2,33 & 0,26 & 2 & 0,89 & 1 & 4 & & T0-T2 & 0,625 & & T1-T2 & $>0,9999$ \\
\hline & T2 & 2,25 & 0,22 & 2 & 0,75 & 1 & 4 & & T0-T3 & $>0,9999$ & & T1-T3 & $>0,9999$ \\
\hline & T3 & 2,25 & 0,22 & 2 & 0,75 & 1 & 4 & & T1-T2 & 0,3125 & & T2-T3 & $>0,9999$ \\
\hline
\end{tabular}

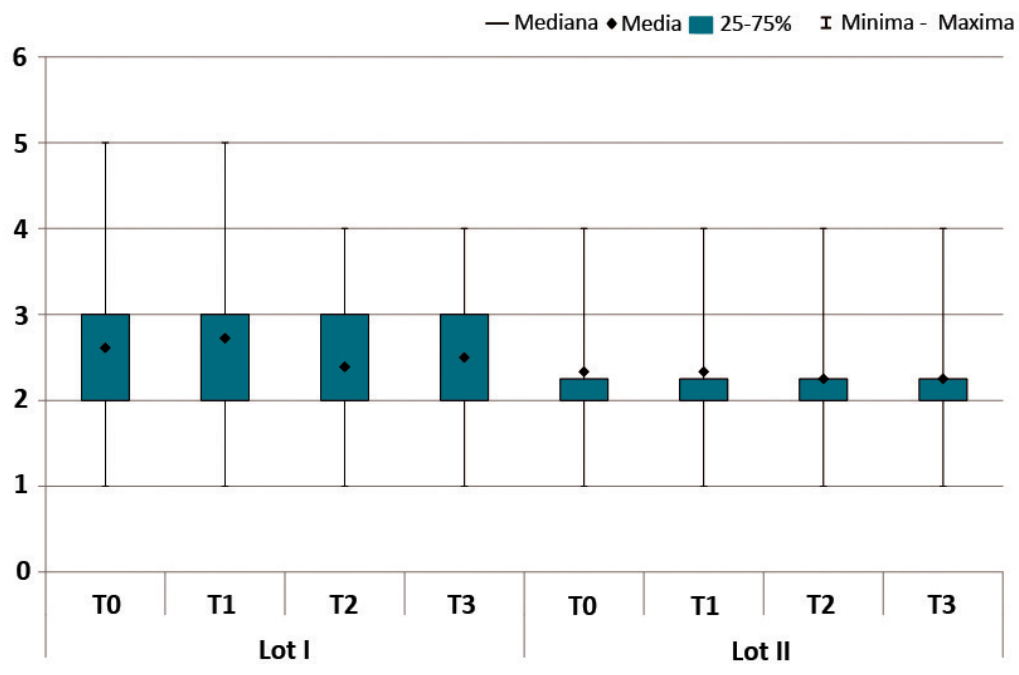

FIGURA 6. Profunzimea la sondare mezio-linguală pentru lotul I şi lotul II pe o perioadă de 3 luni

semnificative $(\mathrm{p}>0,05)$ între cele 2 loturi în niciunul dintre momentele de timp studiate. La analiza statistică a valorilor PA-MV pentru probe perechi, în cazul lotului I, valorile din momentele T0, T1 şi $\mathrm{T} 2$ sunt identice. Între oricare dintre aceste momente de timp şi T3, nu au fost observate diferenţe statistic semnificative $(p>0,05)$. În cazul lotului II, valorile PA-MV sunt identice, egale cu zero, în toate cele 4 momente de timp.

La analiza statistică a valorilor PA-DV (pierdere de ataşament disto-vestibulară) pentru probe neperechi nu au fost observate diferenţe statistic semnificative $(p>0,05)$ între cele 2 loturi în niciunul dintre momentele de timp studiate. La analiza statistică a valorilor PA-DV pentru probe perechi, în cazul lotului I, valorile din momentele $\mathrm{T} 0$ şi $\mathrm{T} 3$, respectiv $\mathrm{T} 1$ şi T2 sunt identice. Între T0-T1, T0-T2, T1-T3, T2-T3 nu au fost observate diferenţe statistic semnificative $(p>0,05)$. În cazul lotului II, valorile PADV sunt identice, egale cu zero, în toate cele 4 momente de timp.

La analiza statistică a valorilor PA-DL (pierdere de ataşament disto-linguală) pentru probe nepe- rechi nu au fost observate diferenţe statistic semnificative $(\mathrm{p}>0,05)$ între cele 2 loturi în niciunul dintre momentele de timp studiate.La analiza statistică a valorilor PA-DL pentru probe perechi, în cazul lotului I, valorile din momentele T0, T1 şi T2 sunt identice. Intre oricare dintre aceste momente de timp şi T3 nu au fost observate diferenţe statistic semnificative $(p>0,05)$. În cazul lotului II, valorile PA-DL sunt identice, egale cu zero, în toate cele 4 momente de timp.

La analiza statistică a valorilor PA-ML (pierdere de ataşament mezio-linguală) pentru probe neperechi nu au fost observate diferenţe statistic semnificative $(p>0,05)$ între cele 2 loturi în niciunul dintre momentele de timp studiate. La analiza statistică a valorilor PA-ML pentru probe perechi, în cazul lotului I, valorile din momentele $\mathrm{T} 0$ şi $\mathrm{T} 3$, respectiv $\mathrm{T} 1$ şi T2 sunt identice. Între T0-T1, T0-T2, T1-T3, T2-T3 nu au fost observate diferenţe statistic semnificative $(p>0,05)$. În cazul lotului II, valorile PAML sunt identice, egale cu zero, în toate cele 4 momente de timp. 


\section{DISCUȚII}

Prezentul studiu a avut în vedere evaluarea indicilor de placă și de sângerare, a profunzimii la sondare și a pierderii de atașament la 30 de restaurări posterioare directe realizate la 24 de pacienți, prin două tehnici diferite, tehnica bulk fill și tehnica de refacere a peretului proximal, folosind două materiale recent introduse pe piața materialelor dentare, și anume materiale ceramice modificate organic (ormoceri). Materialele ormocere prezintă în general o contracție de polimerizare și o contracție volumetrică reduse [10], rezistență la uzură, rezistență la fractură și un modul de elasticitate intermediară [11], comparativ cu compozitele convenționale.

Există puţine studii care să releve performanța clinică și comportamentul in vivo al materialelor ormocere, dar cele care există, realizate pe o perioadă de 5 ani, au prezentat rezultate comparabile cu compozitele convenționale $[12,13]$.

Materialele de restaurare, în special în restaurările de clasa a II-a, pot duce la afectarea mucoasei orale prin mecanisme fizice sau chimice. Totodată, materialele de restaurare pot influența în mod direct sau indirect evoluţia unei gingivite existente şi prezintă un efect sinergic cu placa bacteriană, amplificând semnele inflamatorii [14].

Evaluarea indicilor de placă pe o perioadă de 3 luni, în studiul de față, nu a relevat diferențe statistic semnficative între cele două loturi. La lotul I au fost înregistrate scăderi semnificative ale valorilor indicilor de placă pentru 12 dintre cazurile evaluate, iar pentru ceilalți dinți experimentali au fost înregistrate aceleași valori ale indicilor de placă și în T0 și în T3. La lotul II au fost înregistrate, de asemenea, scăderi semnificative ale valorilor indicilor de placă pentru 6 dintre situațiile evaluate, în T3 valorile fiind mai scăzute comparativ cu T0, iar pentru ceilalți dinți experimentali aferenți lotului au fost înregistrate aceleași valori ale indicilor de placă în toate momentele de evaluare.

Evaluarea indicilor de sângerare pe o perioadă de 3 luni nu a relevat diferențe statistic semnificative între cele două loturi. La lotul I au fost înregistrate scăderi semnificative ale valorilor indicilor de sângerare pentru 9 dintre cei evaluați, iar pentru 3 dintre cazurile evaluate au fost înregistrate creșteri ale valorilor indicilor de sângerare în T3 comparativ cu T0. Ceilalți dinți experimentali din lot au în- registrat aceleași valori ale indicilor și în T0 și în T3. La lotul II au fost înregistrate, de asemenea, scăderi semnificative ale valorilor indicilor de sângerare pentru 6 dintre cei evaluați, iar ceilalți dinți experimentali din lot au înregistrat aceleași valori ale indicilor de sângerare și în T0 și în T3.

Datele relevate de prezentul studiu sunt în contradicție cu un studiu clinic, realizat de AL-Sanjary SA și Gasgoos SS, care au evaluat indicii de placă și indicii de sângerare ai unui grup de restaurări compozite și ai unui grup de restaurări din amalgam comparate cu dinții omologi din cavitatea orală nerestaurați, deoarece autorii au raportat o creștere a indicilor de placă și de sângerare la grupul de restaurări compozite comparativ cu grupul control [15].

În ceea ce privește evaluarea profunzimii la sondare și a pierderii de ataşament, analiza statistică nu a relevat diferențe statistic semnificative între cele două loturi. Atât la lotul I, cât și la lotul II nu au fost înregistrate diferențe între măsurătorile realizate în T0 comparativ cu cele din T3, înregistrându-se aceleași valori ale profunzimii la sondare și ale pierderii de ataşament în toate cele patru momente de evaluare.

Datele obținute sunt în concordanță cu un studiu realizat de către Bertoldi $\mathrm{C}$ şi colab., care au evaluat profunzimea la sondare a 29 de restaurări compozite directe pe o perioadă de 3 luni. Autorii au raportat că nu au fost înregistrate modificări la măsurătorile profunzimii la sondare pe perioada de evaluare [16].

\section{CONCLUZII}

Deși nu s-au găsit diferențe statistic semnificative între cele două loturi pe perioada de evaluare de 3 luni, au fost observate între TO (momentul 0) și T3 (evaluare la 3 luni) unele modificări ale valorilor indicilor de placă și de sângerare, înregistrânduse scăderi ale acestora pentru jumătate dintre dinţii experimentali ai ambelor loturi.

Nu s-a găsit nici o diferență statistic semnificativă între materialele utilizate și tehnicile de realizare a restaurărilor, în ceea ce privește profunzimea la sondare și pierderea de ataşament, valorile înregistrate fiind aceleaşi în TO (momentul O) ca și în T3 (evaluare la 3 luni) pentru ambele loturi evaluate. 
Materialele ormocere și tehnicile de restaurare tehnica de refacere a peretului proximal - nu au influențat negativ niciunul dintre parametrii parodontali evaluați. utilizate în prezentul studiu - tehnica bulk fill și

\section{Menţiune}

Acest articol a fost realizat în cadrul Proiectului de Cercetare Doctorală susținut de Universitatea de Medicină și Farmacie „Iuliu Hațieganu“, Cluj-Napoca, România, nr. contract 1300/10/ din13.01.2017 și 1680/5/ din 19.01.2018.

Conflict of interest: none declared Financial support: none declared

\section{BIBLIOGRAFIE}

1. Heck K, Manhart J, Hickel R, Diegritz C. Clinical evaluation of the bulk fill composite QuiXfil in molar class I and II cavities: 10-year results of a RCT. Dent Mater. 2018;34(6):e138-e147.

2. Torres CRG, Rêgo HM, Perote LC, Santos LF, Kamozaki MB, Gutierrez NC, Di Nicoló R, Borges AB. A split-mouth randomized clinical trial of conventional and heavy flowable composites in class II restorations. J Dent, 2014;42:793-799.

3. Giachetti L, Scaminaci Russo D, Baldini M, Goracci C, Ferrari M. Reparability of aged silorane with methacrylatebased resin composite: Micro-shear bond strength and scanning electron microscopy evaluation. Oper Dent 2012;37(1):28-36.

4. Kidd EA. Microleakage: A review. J Dent 1976;4(5):199-206.

5. Cunha LG, Alonso RC, Santos PH, Sinhoreti MA. Comparative study of the surface roughness of ormocer-based and conventional composites. J Appl Oral Sci 2003;11(4):348-353.

6. Fleming GJ, Hall DP, Shortall AC, Burke FJ. Cuspal movement and microleakage in premolar teeth restored with posterior filling materials of varying reported volumetric shrinkage values. J Dent 2005;33(2):139-146.

7. Admira Fusion, Instructions for use. VOCO, GmbH, 2020.

8. Roman A. Parodontologie 1. Noțiuni de bază. Cluj-Napoca: Editura Medicală Universitară „luliu Hațieganu“, 2017, pp. 71-74.

9. Ciurea A, Micu IC, Roman A, Condor D, Soancă A. Alogritm clinic de restaurare directă a cavităților de clasa a II-a. Revista Română de Stomatologie, 2019;65(4):347-352.
10. Pick B, Pelka M, Belli R, Braga RR, Lohbauer U. Tailoring of physical properties in highly filled experimental nanohybrid resin composites. Dent Mater. 2011;27:664-669.

11. Manhart J, Kunzelmann K-H, Chen HY, Hickel R. Mechanical properties of new composite restorative materials. J Biomed Mater Res, 2000; 53:353-361.

12. Bottenberg $P$, Alaerts $M$, Keulemans F. A prospective randomised clinical trial of one bis-GMA-based and two ormocer-based composite restorative systems in class II cavities: Three-year results. J Dent. 2007;35:163-171.

13. Bottenberg P, Jacquet W, Alaerts M, Keulemans F. A prospective randomized clinical trial of one bis-GMA-based and two ormocerbased composite restorative systems in class II cavities: Five-year results. J Dent. 2009; 37:198-203.

14. Banihashemrad SA, Mokhtari MR, Mogaddas MJ, Farazi F, Garajian A. Clinical Evaluation of Periodontal Parameters in Correct Marginal Dental Restorations. JNKUMS 2013;4(4):535-41.

15. AL-Sanjary SA, Gasgoos SS. Effect of Class II Amalgam and Composite Restorations on Periodontal Health of Posterior Teeth: An in vivo study. Journal of Oral and Dental Research 2017;4:89-92.

16. Bertoldi C, Monari E, Cortellini P, Generali L, Lucchi A, Spinato S, Zaffe D. Clinical and histological reaction of periodontal tissues to subgingival resin composite restorations. Clin Oral Investig. 2020;24(2):1001-11. 